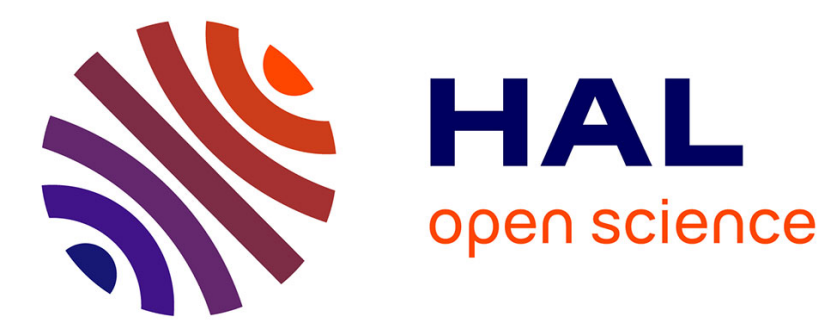

\title{
Supply Chain and Value Chain Engineering - Review
}

Priya Rajesh Shankar, Vincent Aroulmoji

\section{To cite this version:}

Priya Rajesh Shankar, Vincent Aroulmoji. Supply Chain and Value Chain Engineering - Review. International journal of advanced Science and Engineering, 2020, 7 (2), pp.1691-1699. hal-03093012

\section{HAL Id: hal-03093012 \\ https://hal.science/hal-03093012}

Submitted on 3 Jan 2021

HAL is a multi-disciplinary open access archive for the deposit and dissemination of scientific research documents, whether they are published or not. The documents may come from teaching and research institutions in France or abroad, or from public or private research centers.
L'archive ouverte pluridisciplinaire HAL, est destinée au dépôt et à la diffusion de documents scientifiques de niveau recherche, publiés ou non, émanant des établissements d'enseignement et de recherche français ou étrangers, des laboratoires publics ou privés. 


\section{Supply Chain and Value Chain Engineering - Review \\ Rajesh Shankar Priya ${ }^{1 *}$, Vincent Aroulmoji ${ }^{2}$ \\ ${ }^{1}$ Teesside University, Middlesbrough TS1 3BX, United Kingdom \\ ${ }^{2}$ Centre for Research \& Development, Mahendra Engineering College, Mahendhirapuri, \\ Mallasamudram 637503, Namakkal District, Tamil Nadu, India}

ABSTRACT: Supply chain is a widely discussed topic in the last decades. The Just-in-Time concept in manufacturing was a massive success towards the end of the millennium. The Just-In-Time delivery has become a crucial indicator of a company's competitive advantage. Whilst Supply Chain is an integral part of logistics, this paper systematically reviews the fundamentals of supply chain including the definition and difference between a value chain and a supply chain in an academic context, including some key supply chain management principles

KEYWORDS: Supply Chain, Value Chain, Productivity, Supply Chain Management, Engineering, Logistics, LEAN

\section{INTRODUCTION}

The terminology supply chain has evolved and risen to eminence over the last decade [1]. The corporate have started using supply chain in their executive strategies more frequently [2]. Forrester [3] introduced the theory of distribution management and argued that the operational dynamics with the distribution management can influence the productivity and performance of functions of engineering, research, sales and marketing [4]. The topic of distribution identifies key management issues and illustrates the key dynamics of business [3]. Despite the topic being four decades old, Forrester [3] identified key issues of distribution management that relates to the contemporary "Supply Chain Management" issues and since then Supply Chain Management(SCM) has become a topic of priority in marketing, distribution, transportation and logistics related topics [5].

The key reasons for the rise of supply chain relate to these important factors:

1) Multi-national corporations are acting with numerous global suppliers and not dependent any more on local suppliers [4].

2) The globalisation of suppliers requires strategies that are effective and still able to maintain closer relations with the suppliers [1].

3) Customers are used to faster and reliable deliveries and it is now a definite requirement in a market than seen as a competitive advantage [6].

4) The competition globally is not only based on product quality but in combination with the performance of the delivery [7].
5) Companies are extremely flexible in this generation and this leads to uncertainty of new market place [8].

Supply chain (SC) has gained its popularity, but it remains a very ambiguous topic with different terminologies, often leading to confusion both in academia and in industry. Supply chain is often viewed as a operational flow of materials, some term supply chain as a management philosophy and it is also widely discussed as a process used for distribution management $[9,10]$. Researchers have conceptually framed supply chain management as an inherited system of vertical integration in one hand and a management mantra on the other hand [11]. Ross [5] argues that the supply chain management in companies often cause limitation when applying in a practical context due to the management's understanding of its complicated terminology. The supply chain according to Masters and La Londe [12] is a set of companies that distribute materials to a forward chain of interfacing suppliers or end users [4]. The main ingredient of a SC is a mix of product assemblers, whole sellers, logistics companies, component manufacture and even merchants. The definition of SC concepts is not excluding the final customer who seems to be an integral part of the chain. An another definition of SC relates to organizations that are involved in creating value to the end customer with multiple streams namely upstream (supply) and downstream(distribution) by focussing different entities in a supply chain including the end customer [13]. In this context, a supply chain is defined of organizations or individuals directly involved in supply and distributions flows of technology, products, service, financials and information from an origin to a

*Corresponding Author:R.ShankarPriya@tees.ac.uk

Received: 05.09.2020 Accepted: $15.10 .2020 \quad$ Published on: 01.11.2020

Rajesh Shankar Priya \& Vincent Aroulmoji 
customer $[4,13]$. The definitions of SC identify three degrees of supply chain intricacy namely [4]:

1) A simple supply chain

2) An extended supply chain

3) An ultimate supply chain

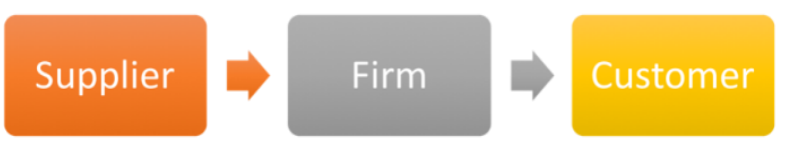

Figure 1 A direct Supply chain

A simple and a direct supply chain consists of a firm with a distributor or supplier and an end user(customer) involved in supply or distribution flow of services, products and any vital information as illustrated in Fig. 1. An extended supply chain holds information of the next supplier and customers relating to the next supplier all involved in supply and distribution of products as illustrated in Fig. 2. An ultimate supply chain integrates all firms involved in all kinds of supply or distribution flow and information from the ultimate supplier to the ultimate customer [4]. The complexity of the ultimate supply chain is illustrated in Fig 3.

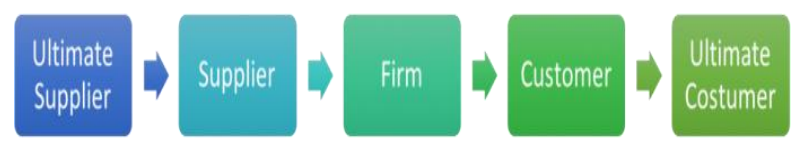

Figure 2An extended Supply Chain

The ultimate supply chain can reach different complexity levels when providing various services with different levels of information, provided to the supplier. In more complex supply chains, various functions are involved to optimise the efficiency and performance [14]. As most of the organizations are involved in numerous supply chains, there is a potential for countless supply chain configurations [4]. A company like Tesco can be involved in a part of supply chain for retail, hardware and many different products and this illustrates the network of different supply chain process. In another illustration, Airbus finds Rolls-Royce to be a customer in one of its chain, a partner in a different, a supplier in a separate case and eventually a competitor on the ultimate. As the research literature indicates the customer to be a member of the supply chain [13], retailers like Tesco can be a part of Supply(upstream) and Distribution(downstream) flow that compound a supply chain. In Table 1, a detailed academic definition of Supply chain and its management aspect is provided.

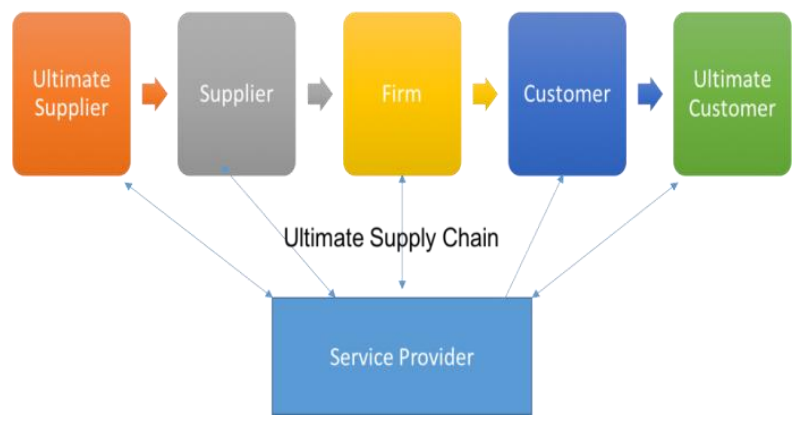

Figure 3The Ultimate Supply Chain

\section{Supply Chain Management}

The SCM often reflects SC as a single entity, than a multiple, fragmented function performing its individual task $[11,16,9,10]$, this enables the whole SCM to optimize the concept of partnerships in to multi firm level to manage the flow of materials from the supplier to the end user [15]. The objective of the SCM is to synchronize all SC activities, enabling a value creation window [19]. The SCM activities suggest that the SCM should not only focus on the logistics part of the chain but to integrate the whole value creation part of the chain, driving supply chain members to have a customer orientation view $[1,9,10]$.

The literature recommends (Table 2) a coordinated SCM approach to have the following dynamics for value creation and efficient performance:

1. An integrated system approach in viewing the SC as a whole entity and managing the flow management of materials from the distributor/supplier to the ultimate enduser/customer.

2. A convergence strategy for multi-firm and intra firm operations reaching towards an objective of committed and long-term cooperation methodologies.

3. Customer orientation and focus in creating unique value leading to customer satisfaction.

4. Define SCM activities that permit the management to behave consistent with the practices.

5. Envision partnership to be a long-term perspective.

6. Foster new methods of sharing data.

7. Categorize operational coordination in to BuyerVendor, Production-distribution and Inventorydistribution. 
Table 1: Research definition of Supply Chain

\begin{tabular}{|l|l|}
\hline Jones 1985) [15] & $\begin{array}{l}\text { The process that deals with the entire flow of materials from the } \\
\text { distributors through the customer or the end users. }\end{array}$ \\
\hline (Houlihan 1988)[16] & $\begin{array}{l}\text { a)The supply chain on its own is said to be a single process and different } \\
\text { segments in the chain like purchasing, distribution and sales are not } \\
\text { fragmented and responsible for the functional areas. b) SCM is significantly } \\
\text { dependent on the strategic decisions taken along the chain while supply is a } \\
\text { shared objective on every fragmented segment of the chain, affecting the } \\
\text { total cost and the market share. c) SCM demands different inventory } \\
\text { dynamics which balances the mechanism of last, not first d) The approach } \\
\text { of interfacing must be ignored, and a method of integration needs to be } \\
\text { forced. }\end{array}$ \\
\hline (Stevens 1989)[17] & $\begin{array}{l}\text { The SCM with various requirements need to be optimised with a } \\
\text { synchronized flow of materials to balance low inventory management, low } \\
\text { unit cost and still maintain the level of customer service demanded by the } \\
\text { customer. }\end{array}$ \\
\hline (La Londe, Bernard J. & $\begin{array}{l}\text { The SCM strategy demands a long-term partnership and agreement } \\
\text { between different firms integrating within the chain with a trust and } \\
\text { commitment relationship, able to share demand and sales data and the } \\
\text { integration of such data for mutual benefit. }\end{array}$ \\
\hline (Cooper et al. 1997b)[1] & $\begin{array}{l}\text { SCM is a illustrated philosophy of managing flow of a distribution channel } \\
\text { from supplier to the ultimate end user. }\end{array}$ \\
\hline (Trent \& Monczka 1998)[18] & $\begin{array}{l}\text { SCM facilitates the sourcing, flow and control of materials using a total } \\
\text { system analogy across a multiple tire of suppliers. }\end{array}$ \\
\hline
\end{tabular}

Table 2: Coordinated SCM Management (Source adapted fromThomas \& Griffin, 1996)

\begin{tabular}{|l|l|l|}
\hline Buyer-Vendor & Production-Distribution & Inventory-Coordination \\
\hline (Monahan 1984) [20] & (Williams 1981) [25] & (Clark 1960) [30] \\
\hline (Lee 1986) [21] & ( Ishii ,Takahashi 1988) [26] & (Maxwell \&William 1983) [31] \\
\hline (Banerjee 1986) [22] & (Haq \&Noorul 1991) [27] & (Antony 1988) [32] \\
\hline (Goyal 1988) [10] & (David 1993) [28] & (Mordechai 1997) [33] \\
\hline (Kohli 1994) [23] & (Pankaj 1994) [29] & (Eijs 1994) [34] \\
\hline (Kim,Jong-Il 1994) [24] & & \\
\hline
\end{tabular}

\section{Supply Chain Management activities}

The competitive $21^{\text {st }}$ century firms require an environment to incorporate customer and suppliers through an external integration in a unified behavioural pattern [35]. Any such extension with a unified behavioural pattern is defined by Bowerhox and Closs [35] as SCM. This pattern is a coordinated pattern between partners in the supply chain such as carriers and manufactures to counter the needs of the customer in a unified behaviour but in a dynamic way [36]. In correspondence to the unified behaviour, both parties require to share information in a mutual context, not only planning purposes but also to monitor constantly the process in the chain $[19,1,37,9]$. The effectiveness of the chain is proportional to the information flow, the more frequent the information is shared, the more effective the chain remains [1]. The information is not purely technical in nature but also includes sales promotion strategies, market forecast and such kind of data reduces the uncertainty between the SC partners and the generate enhanced performance $[38,39,40]$. The effectiveness of the SCM management additionally lies on the jointly sharing of liability \& benefits and it is normally a long-term relationship [11]. Collaboration is a vital component for an effective SCM [9]. Collaboration is not limited to singular outcomes but it is often a multi-facet relationship to generate superior mutual growth over a long duration of time [41]. Collaboration does not stop at a particular transaction but should happen at all levels of management and operational level, usually involving multi-functional coordination across the SC partners $[1,42,43]$. The SCM activities in a chain must have a similar goal and focus on customer service through a policy that allows participants to be more effective at lower cost levels [44]. The policy needs to be compatible in consideration with the cultural aspect of management practices. The assimilation of multiple best practices lead to a consistent implementation of SCM from sourcing to manufacturing to distribution across the SC $[1,19,45,9]$ 


\section{Supply Chain Integration}

Stevens [17] recognized four significant stages of SC integration and elaborated them in the following details:

Baseline: This is a representation of base line case characterised with staged inventories within an independent company and the details associated with the functional segregation of the incompatible systems within the function of the supply chain.

Functional Integration: This is the stage when the internal integration is focussed characterized by cost reduction rather than productivity improvement, buffer in the inventory, trade-offs and responsive customer service

Internal Integration: in this stage, firms focus tactically with mid-term emphasis on efficiency and characterized by full visibility of purchasing through distribution.

External Integration: The scope at this stage is to recognize the integration of the SC beyond the company to embrace suppliers and customers.

Table 3: Supply Chain Integration based on Steven's Model

\begin{tabular}{|l|l|l|}
\hline Stage 1 & Base Line & $\begin{array}{l}\text { Identification and } \\
\text { understanding of } \\
\text { material flow from } \\
\text { purchasing to } \\
\text { distribution }\end{array}$ \\
\hline Stage 2 & $\begin{array}{l}\text { Functional } \\
\text { Integration }\end{array}$ & $\begin{array}{l}\text { Identification and } \\
\text { understanding the } \\
\text { functionality of } \\
\text { material flow } \\
\text { management, } \\
\text { manufacturing } \\
\text { management and } \\
\text { distribution practices }\end{array}$ \\
\hline Stage 3 & $\begin{array}{l}\text { Internal } \\
\text { Integration }\end{array}$ & $\begin{array}{l}\text { Internal integration of } \\
\text { material management, } \\
\text { manufacturing } \\
\text { management and } \\
\text { distribution practices }\end{array}$ \\
\hline Stage 4 & $\begin{array}{l}\text { External } \\
\text { Integration }\end{array}$ & $\begin{array}{l}\text { Integration of } \\
\text { suppliers, internal } \\
\text { supply supply and } \\
\text { customers. }\end{array}$ \\
\hline
\end{tabular}

\section{Bullwhip Effect}

The customer dictates the actual demands for a product and its materials [46]. Despite this demand,the actual product gets perverted down the SC, for e.g. if the real demand for a client is 800 units, the merchant who does the retailing might order 1000 units (an excess of 200 units) to guarantee the stock availability, the supplier eventually orders 200 more from the manufacturer (excess of 400 than the client's original order) as bulk ordering might have its discounts as well have enough stock for guaranteed shipment and ensuring the economy of the scale of production. An order of 800 units makes the manufacturers to produce 1200 and these subjects, the retailing merchants to increase demand by reducing prices or attracting new customers by promotions to the buy the excess units. This phenomenon where orders to supplier have a larger demand or variance than sales to the buyer is termed as bullwhip effect or whiplash effect [21]. There are many factors contributing this effect in the SC [47]:

1) Demand forecasting: Higher dependence in demand information for estimation for a product that accounts to a lot of fluctuation.

2) Order Batching: Surges in demand happen any time and similarly, sluggish demand pattern appear any time, but firms do not place an order with the supplier in a short timeframe, instead the pattern of ordering often is monthly of fortnightly.

3) Price Variations: Promotional products often cause an effect in buying patterns (for customers). As the surge of production increases and with distorted demand information to handle, the chain faces a huge traction.

4) Rationing Game: Many customers tend to distort information because of strategic decisions by overstating demands and cancel when the supply when the supply is adequate again to ration.

\section{The Value Chain (VC) Perspective}

The value chain's existence can be dated back to over 30 years, but it remains a very unclear concept [48]. The supply chain perspective provided us an understanding that the current generation of SC is based on customer intimacy and most often the SC are fully synchronized with suppliers and the endcustomers. The value chain concept was developed by Porter [49]. Firms often create value by either acquiring new materials or generating new services and utilizing them to make it profitable [50]. A value chain is a set of defined activities that a company executes to create additional impact in the terms of value for its customer [49]. Porter [49] proposed a general value strategy that companies can adopt to examine all their activities and see how all these valuegenerating parameters are inter-connected. Porter [49] argues that the way the activities are performed determines the costs and affects the profit/loss ratio of the company [51].The value system is formed when value chain activities are linked between firms [48]. Porter [49] identified nine generic value added activities operating in a firm. Rather than looking at departments or accounting cost types, Porter's Value 
Chain focuses on systems, and how inputs are changed into the outputs purchased by consumers. Using this viewpoint, Porter [49] described a chain of activities common to all businesses, and he divided them into primary and support activities

\section{Primary Activities}

Primary activities are directly connected to the development, sales and servicing of a product or service and they normally consist of these parameters:

- Inbound logistics - This process is connected to inward distribution of inputs internally in an organization. The supplier's relationship is vital for value creation [49]

- Operations - The process to transform the inputs generated internally to outcome for customers. The operational methods the company implements is vital for value creation [49]

- Outbound logistics - The process where the product gets delivered to the customers and all vital steps like collection, storage and distribution create value [49]

- Marketing and sales activities - The process that dictates the client to purchase the products/services the company offers. The rewards, communication and platform of communication creates value [49]

- Service - The process to create servicing of the product in accordance to the maintenance and the warranty contracts issued by the customer to the clients [49]

\section{Support Activities}

The support activates facilitate the primary activities for e.g. the procurement function can support in operations in a standard way but can additionally facilitate marketing and sales in a different activity, creating value to the chain [49].

- Procurement (purchasing) - The backbone of the company to identify vendors and negotiating the best contracts for purchasing materials and components.

- Human resource management - This manages the recruiting, training and rewards for the workers of the companies. People are considered to the best resource available to the company and a fine tuned HR department with best practices methodology can definitely create value to the company as well with the clients handling with the company.

- Technological development - Enabling technology is vital component for businesses worldwide and technologies often function as enablers reducing operational time and at the same time maintain technical excellence and reducing costs for the company.
- Infrastructure - Companies build infrastructure to support their systems and minimize hindrance to its operations, administration and general management.

The primary focus however remains on the benefits the company can provide to its customers by creating value in the activities (direct or indirect) the companies perform [52]. For every primary activity a company performs, there are a set of sub-activities as illustrated in Figure 4, that create value [53]. These activities are defined as:

1) Direct Activities which create value by themselves for e.g. sales activity

2) In-direct activities facilitate easy operations of direct activities by maintaining the customer account management required for sales to happen.

3) Quality Assurance supports the direct and indirect activities in compliance of keeping the standards required while the sales process is happening.
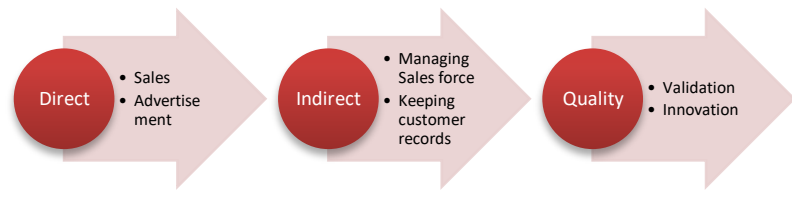

Figure 4 Identification of Sub-activities for primary activities

By identification of sub activities as illustrated in Figure 5 for each support activity, the company creates value within each primary activity [54]. For e.g. the HR creates value to operations, purchasing, and development and even in Infrastructure development.
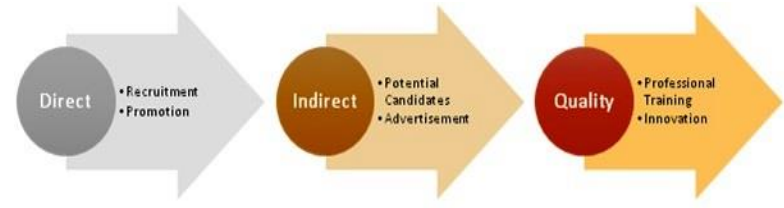

Figure 5 Identification for sub-activities for secondary activities Differences and Similarities between a Supply Chain
and a Value Chain

Porter [49] defines value as a subjective experience, depending on the context and occurs though the provision of resources [48]. The value experience flows from the customer, who is the recipient of resources [14]. This differentiates the value chain from Supply chain, as the sequence of SC initiates from product

\section{Rajesh Shankar Priya \& Vincent Aroulmoji}


request to customer, while the value chain operates from customer request to a product $[55,56]$. The objective of any SC is to satisfy the customer whereas the value chain provides a competitive advantage for the customer [57]. The concept of SC facilitates the operational management team by acting as a conveyance in the chain of events [1] while the concept of value chain originates from a business management perspective providing value addition to the chain [53]. The SC and VC as illustrated in Figure 6 is regarded as a complimentary view of an extended business process, enabling the flow of products in one way that is aligned with the value of demand and cash flow on the other. As values can be generated between business to other businesses or between a company and a consumer, it is vital to define value exchange between these 2 different matrixes of Business to Business(B2B) and Business to Customer(B2C) [58]. There can be up to 3 different forms of values in business generation in a commercial transaction (B2B) $[59,60,61,62,48]$ :

1) The intellectual value

2) The institutional value

3) The personal value

The intellectual value is related to the resources being available and it occurs in all exchanges during the chain. The institutional value occurs in a context of exchange relating to ethical standards, prestige and culture of the association, brand value and reliability. The personal value is derived from the individual experiences within the exchange of resources and its associated benefits linked in a commercial context [48].

In the consumer context (B2C), the value is often described as [51]:

1) The product value

2) The service value

3) The excellence value

The product value is often derived from a source or supply, while the service value is depicted around the service of the product in a form of a call-centre, repair, maintenance or warranty service. The excellence value is a new generation of service not only concentrating on customer being satisfied but also making the customer successful [1]. The value which is generated from the customer needs are categorized as "value added categories" and the activities that do not correspond the needs, could be eliminated in synchronisation with the LEAN thinking mechanism [63]. By fine-tuning the value generation process that generates goods and services valued by the customer, a consolidated resource management plan can be established improving productivity and performance of the company, enhancing the corporate strategies focussing on operational excellence.

\subsection{The importance of Value Chain}

The industrial engineering started strategizing on operational efficiency, focussing oriented analysis of production operations and SC from a value chain perspective [48]. The main drivers or trends that lead to value chain importance as illustrated in Figure 7 are as follows:

1) Increasing Innovation and competition focus in the corporate strategy.

2) Changing business and governance models with in an industry.

3) Global supply and production.

4) Management communication

The value deriving from the product is not only seen as an indicator of market place performance but also as a measure of satisfaction, consumer confidence and a helping cause for the environment. Similarly, the risk of value exaggeration can cause bubble and crash before taking-off (similar to the IT industry) due to creation and destruction of sudden value parameters not necessarily originating from the customers. The supply chain that synchronizes nicely with the flow of value in the form of customer input, preference and demand will generate value in this current, global and dynamic environment. A reverted, integrated model of supply chain and value chain seen as a single entity is required to optimise material flow and synchronize the product delivery with information, knowledge and inputs from the customers. The holistic approach of product design being integrated with production process, logistics management and inputs from customer demands will enhance the SC, propel the business performance of companies, and deliver satisfaction to the customers[69].

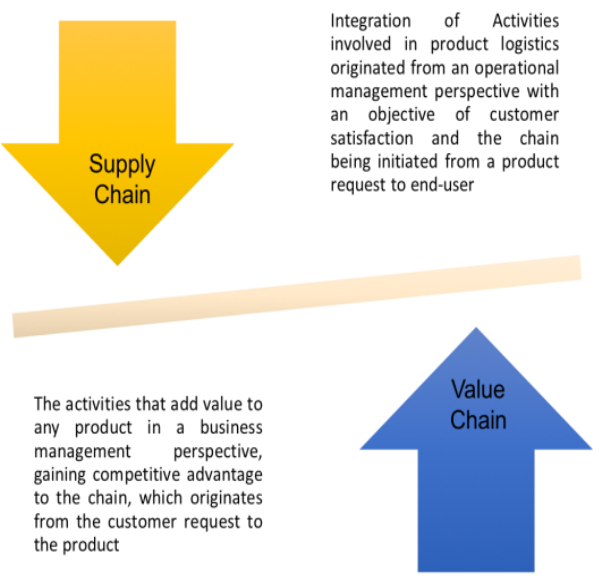

Figure 6Supply Chain Vs Value Chain after $[49,50,51,63,1]$ 


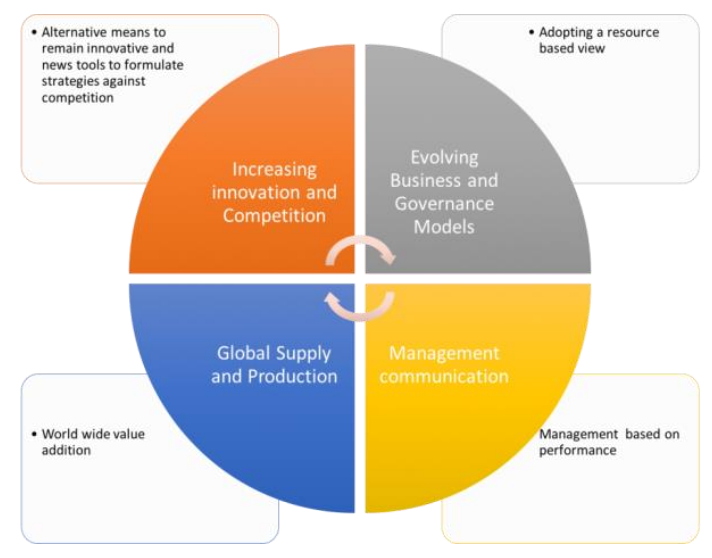

Figure 7: Importance of Value Chain $[64,65,55,66,67,68,69]$

\section{CONCLUSION}

The rise of globalization makes distribution, transportation and logistics related topics more challenging especially when companies are dealing with global suppliers. The strategies that require effective planning for faster and reliable supply is a defining criteria for fostering competitive advantage in business by enhancing performance claims that "The global completion is not only based on product quality or cost but in combination with performance of the delivery". The efficient supply chain management concept of dealing the entire flow of materials from the distributors to the end users is significantly dependent on strategic decisions taken along the chain including careful planning, forecasting and managing inventory dynamics. The emphasis of satisfying the customer and on the same time removing unnecessary transactions in the relationship requires a lean concept of thinking.

\section{REFERENCES}

[1] Cooper, M.C., Lambert, D.M., Pagh, J.D., 1997a. Supply Chain Management: More Than a New Name for Logistics. International Journal of Logistics Management, The, 8(1), pp.1-14.

[2] La Londe, B.J., 1997. Supply Chain Management: Myth or Reality? Supply Chain Management Review, Vol. 1, Spring, pp. 6-7.

[3] Forrester, J.W., 1958. Industrial dynamics: a major breakthrough for decision makers. Harvard Business Review, 36(4), pp.37-66.

[4] Mentzer, J.T. et al., 2001. Journal of Business Logistics, 22(2)1-25.

[5] Ross, D.F., 1988. Competing Through Supply Chain Management. , New York,.

[6] Janvier-James, A.M., 2011. A New Introduction to Supply Chains and Supply Chain Management: Definitions and Theories Perspective. International Business Research, 5(1).
[7] Beamon, B.M., 1999. Measuring supply chain performance. International Journal of Operations \& Production Management, 19, pp.275-292.

[8] Hayes, R.H., Wheelwright, S.C. \& Clark., K.B., 1988. Dynamic manufacturing: Creating the learning organization,

[9] Tyndall, Gene, Christopher Gopal, Wolfgang Partsch, J.K., 1998. Super- charging Supply Chains: New Ways to Increase Value Through Global Operational Excellence. , (New York, NY: John Wiley \& Sons.).

[10] Goyal, S.K., 1988. A Joint Economic-Lot-Size Model For Purchaser and Vendor: A Comment. Decision sciences 19.1 (1988): 236-241.

[11] Cooper, Martha C., L.M.E., 1993. Characteristics of supply chain management and the implications for purchasing and logistics strategy. The International Journal of Logistics Management 4.2, p.13-24.

[12] La Londe, Bernard J., and J.M.M., 1994. Emerging logistics strategies: blueprints for the next century. International journal of physical distribution \& logistics management 24.7, p.: 3547.

[13] Christopher, M., 1992. Logistics \& supply chain management, fourth edition, FT Prentice Hall, London.

[14] Cox, A., 1999. Power, value and supply chain management. Supply Chain Management: An International Journal, 4(4), pp.167-175.

[15] Jones, T., D.W.R., 1985. Using Inventory for Competitive Advantage through Supply Chain Management,.

[16] Houlihan, J.B., 1988. International Supply Chains: A New Approach. Management Decision, 26(3), pp.13-19.

[17] Stevens, G.C., 1989. Integrating the Supply Chains,. International Journal of Physical Distribution and Materials Management,, 8, p.38.

[18] Trent, R.J. \& Monczka, R.M., 1998. Purchasing and Supply Management: Trends and Changes Throughout the 1990s. International Journal of Purchasing and Materials Management, 34(November), pp.2-11.

[19] C.John Langley, J. \& Holcomb, M.C., 1992. Createing Logistics Customer Value. Journal of Business Logistics, 13(2), pp.285-301.

[20] Monahan, J.P., 1984. A quantity discount pricing model to increase vendor profits. 720-726. Management science 30.6 .

[21] Lee, Hau L., and M.J.R., 1986. A generalized quantity discount pricing model to increase supplier's profits. Management Science 32.9, p.1177-1185. APA.

[22] Banerjee, A., 1986. "Note-On A Quantity Discount Pricing Model to Increase Vendor 
Profits, Management Science 32.11, p.15131517.

[23] Rajeev Kohli., Heungsoo Park. 1994. Coordinating buyer-seller transactions across multiple products. Management Science 40.9: 1145-1150.

[24] Kim, Jong-Il, and L.J.L., 1994. The sources of economic growth of the East Asian newly industrialized countries. Journal of the Japanese and International Economies 8.3 235-271

[25] Williams, J.F., 1981. Heuristic techniques for simultaneous scheduling of production and distribution in multi-echelon structures: Theory and empirical comparisons. Management Science $27.3:$ 336-352.

[26] Ishii, K., K. Takahashi, R.M., 1988. Integrated production, inventory and distribution systems. The International Journal of Production Research 26.3 : 473-482.

[27] Haq, A. Noorul, Prem Vrat, A.K., 1991. An integrated production-inventory-distribution model for manufacture of urea: a case. International Journal of production economics 25.1 : 39-49.

[28] Pyke, David F., M.A.C., 1993. Performance characteristics of stochastic integrated production-distribution systems. European Journal of Operational Research 68.1 : 23-48.

[29] Chandra, Pankaj, M.L.F., 1994. Coordination of production and distribution planning. European Journal of Operational Research 72.3 : 503-517.

[30] Clark, Andrew J., H.S., 1960. Optimal policies for a multi-echelon inventory problem.Management science $6.4: 475-490$.

[31] Maxwell, William, et al, 1983. A modeling framework for planning and control of production in discrete parts manufacturing and assembly systems. Interfaces 13.6 : 92-104.

[32] Svoronos, Antony, P.Z., 1988. Estimating the performance of multi-level inventory systems. Operations Research 36.1: 57-72.

[33] Henig, Mordechai, et al., 1997. An inventory model embedded in designing a supply contract. Management science 43.2 : 184-189.

[34] Van Eijs, M.J.G., 1994. Multi-item inventory systems with joint ordering and transportation decisions.International Journal of Production Economics 35.1-3 : 285-292.

[35] Bowersox, Donald J., David J. Closs, O.K.H., 1996. Logistical management. Vol. 6. New York, NY: McGraw-Hill,.

[36] Greene, A.H., 1991. Supply chain of customer satisfaction. Production and Inventory Management Review and APICS News 11.4 : 2425.

[37] Lambert, Douglas M., James R. Stock, L.M.E., Fundamentals of logistics management. McGraw-Hill/Irwin.
[38] Andel, T., 1997. Information supply chain: Set and get your goals. Transportation \& Distribution.

[39] Lewis, Ira, and A.T., 1997. Logistics and information technology: a coordination perspective. Journal of Business Logistics 18.1 : 141. APA.

[40] Griffith, David A., Michael G. Harvey, and R.F.L., Social exchange in supply chain relationships: The resulting benefits of procedural and distributive justice. Journal of operations management 24.2 (2006): 85-98. 2006.

[41] Anderson, James C., J.A.N., 1990. A model of distributor firm and manufacturer firm working partnerships. The Journal of Marketing : 42-58.

[42] Spekman, Robert E., John W. Kamauff Jr, and N.M., 1998. An empirical investigation into supply chain management: a perspective on partnerships. Supply Chain Management: An International Journal 3.2 : 53-67.

[43] Heide, Jan B., G.J., 1990. Alliances in industrial purchasing: The determinants of joint action in buyer-supplier relationships. Journal of marketing Research : 24-36.

[44] Lassar, Walfried M. 1995. Informal channel relationships in logistics. Journal of Business Logistics $16.1: 81$.

[45] Cooper, M.C., Lambert, D.M., Pagh, J.D., 1997a. Supply Chain Management: More Than a New Name for Logistics. International Journal of Logistics Management, 8(1), pp.1-14.

[46] McGrath, Michael E., Michael T. Anthony, and A.R.S., 1992. Product development: success through product and cycle-time excellence. Rbhp Trade Group.

[47] Lee, H.L., Padmanabhan, V. \& Whang, S., 1997. Information Distortion in a Supply Chain: The Bullwhip Effect. Management Science, 43(4), 546-558.

[48] Feller, A., Shunk, D. \& Callarman, T., 2006. Value Chains Versus Supply Chains. BPTrends, March 2006, pp.1-7.

[49] M. Porter, 1985. Competitive Advantage, Creating and Sustaining Superior Performance, The Free Press, New York.

[50] Porter, M., 1980. Competitive Strategy: Techniques for Analyzing Industries and Competitors. Competitive Strategy, 1, p.396.

[51] Clemmer, Jim, 1990. The Three Rings of Perceived Value. The Canadian Manager. 1;15(2):12-15.

[52] Sturgeon, T.J., 2001. How Do We Define Value Chains and Production Networks? IDS Bulletin, 32(3), pp.9-18.

[53] Walters, D. \& Lancaster, G., 2000. Implementing value strategy through the value chain. Management Decision, 38(3), pp.160-178

[54] Chains, V., 2006. The Value Chain Framework. 
Program Manager, pp.1-4. Available at: http://www.12manage.com/methods_porter_va lue_chain.html.

[55] Gereffi, G. Christian, M., 2009. The Impacts of Wal-Mart: The Rise and Consequences of the World's Dominant Retailer. Annual Review of Sociology, 35, pp.573-591.

[56] Sturgeon, T.J., 2008. From Commodity Chains to Value Chains : Interdisciplinary theory building in an age of globalization. Frontiers A Journal of Women Studies, (January), pp.110-135.

[57] Oswald A Mascarenhas, Ram Kesavan, M.B., 2004. Customer value-chain involvement for cocreating customer delight. The Journal of Consumer Marketing. ;21(7):486-496.

[58] McPhee, W., Wheeler, D., 2006. Making the case for the added-value chain. Strategy \& Leadership, 34(4), pp.39-46

[59] Hansen, M.T,Birkinshaw, J. 2007. The innovation value chain. Harvard Business Review, 85(6).

[60] Bobrek, M. et al., 2006. Design approach in management toward to business excellence. , 16(1), pp.184-189.

[61] Brynjolfsson, E., Hitt, L.M., 1996. Productivity , Business Profitability, and Consumer Surplus: Three Different Measures of Information Value. MIS Quarterly, 20(2), pp.121-142.
[62] Ward, P.T., Bickford, D.J.,Leong, G.K., 1996. Configurations of manufacturing strategy, business strategy, environment and structure. Journal of Management, 22(4), pp.597-626.

[63] Womack, J.P., Jones, D.T., 2005. Lean Solutions : How Companies and Customers Can Create Value and Wealth Together. Free Press, (617), pp.1-3.

[64] Smith, A., 1937. The Wealth of Nations, Modern Library, New York, NY.

[65] Hamel, G., Prahalad, C.K., 1996. Competing in the new economy: Managing out of bounds. Strategic Management Journal, 17(3), 237-242.

[66] Friedman, T.L.T., 2005. The world is flat: A brief history of the twenty-first century. New York: Farrar, Straus and Giroux, p.660.

[67] Abrahamson, E., Fairchild, G., 1997. Management Fashion: Lifecycles, Triggers, and Collective Learning Processes. Academy of Management Best Papers Proceedings, 8(1), pp.254-257.

[68] Fine, C.H. et al., 2002. Rapid-response capability in value-chain design. Sloan Management Review, 43, pp.69-75.

[69] Rajesh Shankar Priya, Vincent Aroulmoji. 2020. A Review on Productivity and its Effect in Industrial Manufacturing, Int. J. Adv. Sci. Eng. 6(4) 1490-1499

All (C) 2020 are reserved by International Journal of Advanced Science and Engineering. This Journal is licensed under a Creative Commons Attribution-Non Commercial-ShareAlike 3.0 Unported License. 